See discussions, stats, and author profiles for this publication at: https://www.researchgate.net/publication/320621812

\title{
Galling Insects of the Brazilian Páramos: Species Richness and Composition Along High-Altitude Grasslands
}

Article in Environmental Entomology · September 2017

DOI: $10.1093 / \mathrm{ee} / \mathrm{nvx} 147$

\section{CITATIONS}

4

5 authors, including:

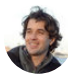

Marcel Coelho

Federal University of Minas Gerais

40 PUBLICATIONS 263 CITATIONS

SEE PROFILE

Rafael Borges

Universidade Federal do Rio Grande do Sul

33 PUBLICATIONS 291 CITATIONS

SEE PROFILE

Some of the authors of this publication are also working on these related projects:

Ethical of scientific papers View project

Project Monograpfh View project
Marco Antonio A. Carneiro

Universidade Federal de Ouro Preto

51 PUBLICATIONS 826 CITATIONS

SEE PROFILE

G. Wilson Fernandes

Federal University of Minas Gerais

509 PUBLICATIONS 10,215 CITATIONS

SEE PROFILE 


\title{
Galling Insects of the Brazilian Páramos: Species Richness and Composition Along High-Altitude Grasslands
}

\author{
Marcel S. Coelho, ${ }^{1,2,5}$ Marco Antônio Alves Carneiro, ${ }^{3}$ Cristina A. Branco, ${ }^{1}$ \\ Rafael Augusto Xavier Borges, ${ }^{4}$ and G. Wilson Fernandes ${ }^{1}$
}

\begin{abstract}
${ }^{1}$ Ecologia Evolutiva \& Biodiversidade/DBG, ICB/Universidade Federal de Minas Gerais, 30161970 Belo Horizonte, Minas Gerais, Brazil, '2Laboratório de Fenologia, Departamento de Botânica, IB UNESP/UNESP Universidade Estadual Paulista, $13506-900$ Rio Claro, São Paulo, Brazil, ${ }^{3}$ Laboratório de Entomologia Ecológica/DEBIO, ICEB/Universidade Federal de Ouro Preto, 354000000 uro Preto, Minas Gerais, Brazil, 'Laboratorio de Botânica, Universidade Federal do Rio Grande do Sul, 9500 Porto Alegre, Rio Grande do Sul, Brazil, ${ }^{5}$ Corresponding author, e-mail: marcel.s.coelho@gmail.com
\end{abstract}

Subject Editor: Deborah Finke

Received 18 May 2017; Editorial decision 16 August 2017

\begin{abstract}
In this work, we investigated the factors that determine the distribution of galling insects in high-altitude grasslands, locally called 'campos de altitude' of Mantiqueira Range and tested whether 1) richness of galling insects decreases with altitude, 2) galling insect richness increases with plant richness, 3) variation in galling insect diversity is predominantly a consequence of its $\beta$ component, and 4) turnover is the main mechanism driving the beta diversity of both galling insects and plants. Galling insect richness did not exhibit a negative relationship with altitude, but it did increase with plant richness. The additive partition of regional richness $(\gamma)$ into its local and beta components showed that local diversity $(\alpha)$ of galling insects and plants was relatively low in relation to regional diversity; the $\beta$ component incorporated most of the regional diversity. This pattern was also found in the multiscale analysis of the additive partition for galling insects and plants. The beta diversity of galling insects and plants was driven predominantly by the process of turnover and minimally by nesting. The results reported here point out that the spatial distribution of galling insects is best explained by historical factors, such as the distribution of genera and species of key host plants, as well as their relation to habitat, than ecological effects such as hygrothermal stress here represented by altitude.
\end{abstract}

Key words: Atlantic Forest, $\beta$ diversity, Biogeography, Campos de Altitude, Richness hypothesis

\section{Introduction}

Galling insects are among the most sophisticated herbivores, being able to control and redirect host plants to their benefit (Abrahamson and Weis 1997, Shorthouse et al. 2005). Insect galls are caused by changes in the pattern of growth and development of plant tissues or organs in response to the actions of an insect inducer (DregerJauffret and Shorthouse 1992), and they are characterized by an increase in the number, size, or both of cells culminating in the formation of a symmetrical structure (Raman 2007). From an evolutionary point of view, galls can be seen as extended phenotypes of insects or their adaptations to feed on tissues of high nutritional quality, while obtaining protection from natural enemies and environmental fluctuations (Price et al. 1986, Weis et al. 1988, Nyman and Julkunen-Tiitto 2000, Stone and Schönrogge 2003).

Globally, galling insects are most species rich in intermediate latitudes $\left(25^{\circ}\right.$ to $38^{\circ} \mathrm{N}$ or S), with warm habitats with sclerophyllous vegetation (Price et al. 1998); however, there is still no consensus regarding the factors that best correlate with galling insect species richness. For instance, studying galling insects at canopy in the Brazilian Amazon, Julião et al. (2014) recorded a high insect richness. These results have extended the biogeographic regions with great galling insects richness from intermediate to equatorial latitudes. The increase in sample effort with standardized methodologies can lead to changes in the distribution of galling insect currently established, adding a dose of chaos to the understanding of the main ecological drivers behind those patterns (see also Ribeiro and Basset 2007). Galling insects richness also decreases monotonically with altitude or possesses a maximum value at intermediate altitudes (Fernandes and Price 1988, 1991; Waring and Price 1990; Fernandes and Lara 1993; Fernandes et al. 1994; Price et al. 1998; Blanche and Ludwig 2001; Lara et al. 2002; Carneiro et al. 2005). Regardless of latitude and altitude, evidence suggests that the species richness of galling insects is greater in xeric than in mesic habitats (Fernandes and Price 1991, 1992; Cuevas-Reyes et al. 2004a). The mechanisms responsible for greater species richness in xeric habitats would involve differential survival and mortality among 
habitats. In xeric habitats, populations of galling insects suffer lower mortality due to natural enemies. In addition, galling insects in xeric habitats are able to overcome high concentrations of phenolic compounds (Fernandes et al. 2005). Since hygrothermal stress varies with latitude/altitude, the latitudinal and altitudinal pattern of galling insect richness has been interpreted as a response to increased stress of habitats at intermediate latitudes and lower altitudes, respectively (Price et al. 1998). Thereto, Mendonça (2001) observed that fire is a common phenomenon in habitats with sclerophyllous vegetation, which would benefit galling insects due to the consequential synchronization in the production of new vigorous branches for them to colonize. Thus, fire could be included within the initial hypothesis of Fernandes and Price (1991) as suggested by Price (2003).

Beside the hygrothermal and nutritional stress, species richness and taxonomic composition of vegetation plays an important role in the richness of galling insect species (Araújo 2013). While Wright and Samways $(1996,1998)$ found species richness of host plants in Fynbos (South Africa) to be the main determinant of species richness of galling insects, other studies considered the host plant richness a poor indicator of the variation in galling insects richness in rupestrian grasslands (Fernandes and Price 1988, Lara et al. 2002) and in Australian savanna (Blanche 2000). These discrepant results can be explained by the fact that in Fynbos galling insects richness per plant species is low and varies very little among different host plants. On the other hand, in rupestrian grasslands, a single plant species (Baccharis concinna Barroso (Asterales: Asteraceae)) possessed $32 \%$ of the galling insect species found in a single habitat, while Qualea (Vochysiaceae) seems to play an important role in Cerrado (Lara and Fernandes 1996, Araújo et al. 2013). In the Australian savanna, species of Eucalyptus L'Hér (Myrtales: Myrtaceae) play the same concentrating role (Blanche 2000). In habitats where the number of galling insect species associated with host plant species is highly variable, the main determinant of galling insects richness would be taxonomic composition and not plants species richness. This high variability in the number of galling insect species can be explained by the presence of 'super-hosts' that greatly increase the galling insect richness (Fernandes and Price 1988, Veldtman and McGeoch 2003, Espírito-Santo and Fernandes 2007, see also Hawkins and Compton 1992).

An as of yet unexplored way of understanding patterns and mechanisms of spatial distribution of galling insect richness and composition is how local and beta diversity contribute to regional species diversity (Medianero et al. 2010, Carneiro et al. 2014). Beta diversity is defined as the change in species composition between sites and (i.e., a relationship between regional and local diversity) can occur exclusively through two processes: turnover and nesting (Baselga and Orme 2012). While turnover refers to the replacement of species from one site to another, nestedness refers to the loss or gain of species, which makes the species of one site a subgroup of those of a richer site (Baselga 2010). Understanding the dimension of the contribution of beta diversity to regional diversity, as well as the predominant processes responsible for beta diversity - whether nestedness or turnover - may help in understanding how galling insect-plant interactions respond to changes to the environmental or at other geographic scales (Whittaker 1972, Medianero et al. 2010, Carneiro et al. 2014, Coelho et al. 2017).

Field studies with standardized sampling effort are scarce in the tropics despite the extensive debate regarding the factors that affect galling insect richness. One way of studying patterns of species distribution is by focusing on their variation along environmental gradients such as altitudinal gradients in mountainous complexes
(Martinelli 2007). Altitudinal variation along mountain ranges represents one of the great biogeographic frontiers to be studied. Mountains are natural laboratories in which to investigate the response of organisms to environmental variation (Lomolino 2001, Beckage et al. 2008, Carneiro et al. 2014). In this work, we investigated the factors that determine the distribution of galling insects in the campos de altitude (high-altitude grasslands) of Mantiqueira Range and test the following hypotheses:

(i) Richness of galling insects decreases with altitude (Fernandes and Price 1988)

(ii) Richness of galling insects increases with plant richness (Southwood 1960, 1961; Wright and Samways 1996, 1998; Gonçalves-Alvim and Fernandes 2001; Oyama et al. 2003; Cuevas-Reyes et al. 2004b)

(iii) Variation in regional diversity of galling insects and host plants is predominantly a consequence of its $\beta$-component (Medianero et al. 2010, Baselga and Orme 2012, Carneiro et al. 2014)

(iv) Turnover is the main mechanism driving the beta diversity of both galling insects and plants (Medianero et al. 2010, Carneiro et al. 2014, Coelho et al. 2017)

\section{Methods}

\section{Study Area}

Grassy fields located at high altitudes were called alpine fields by Barreto (1949) and altimontane fields by Rizzini (1963). However, these classifications encompass ecosystems that, although they are physiognomically similar, differ in their lithological characteristics, geological origins and surrounding matrix, as well as biological dimensions, such as floristic composition (Rizzini 1979). Due to such differences, grassy fields located at high altitudes were subdivided into quartzitic fields and altimontane fields by Rizzini (1979) and later as rupestrian grasslands 'campos rupestres' and high-altitude grasslands 'campos de altitude' by Ferri (1980). High-altitude grasslands occur predominantly on granite rocks and are embedded in a matrix of Atlantic Forest (Moreira and Camelier 1977). The expression high-altitude grasslands is frequently used to denote a set of plant formations dominated by herbaceous species restricted to high altitudes, humid and cold climates in southeastern and southern Brazil, with granite formation, quaternary orogenesis and located within one of the four main floristic domains: Atlantic Forest, Cerrado, Araucaria Forests and Pampas (Safford 1999a,b). The vegetation is dominated by herbs and shrubs. The most common families are Asteraceae, Melastomataceae, Orchidaceae, and Bromeliaceae, and they occur in latitudes where there is a marked dry season (Martinelli 2007). The high-altitude grasslands are called Brazilian Páramos due to the abrupt ecotone between grasslands at the top and wet forests at the bottom of the mountains (see Safford 1999a for a review).

Plant sampling was conducted in high-altitude grasslands of four mountains associated with the Mantiqueira Range: 1) Brigadeiro State Park (1,281-1,889 m), 2) Caparaó National Park (2,106$2,486 \mathrm{~m}), 3)$ Ibitipoca State Park (1,442 - 1,777 m), and 4) Itatiaia National Park (2,240-2,562 m) (Coelho et al. 2013, Carneiro et al. 2014) (Figs. 1 and 2). The altitudinal range of the four mountains together was 1281-2562 m.

The Brigadeiro State Park is located in the forest zone of Minas Gerais between the meridians $42^{\circ} 20^{\prime}$ and $42^{\circ} 40^{\prime} \mathrm{S}$ and the parallels $20^{\circ} 20^{\prime}$ and $21^{\circ} 00^{\prime} \mathrm{W}$ (Engevix 1995). Its lithology is predominantly comprised of granite formations. The climate is classified as mesothermic medium $\left(\mathrm{CW}_{\mathrm{b}}\right)$, with an annual average temperature of $18^{\circ} \mathrm{C}$ and precipitation of $1,300 \mathrm{~mm}$. The predominant vegetation 


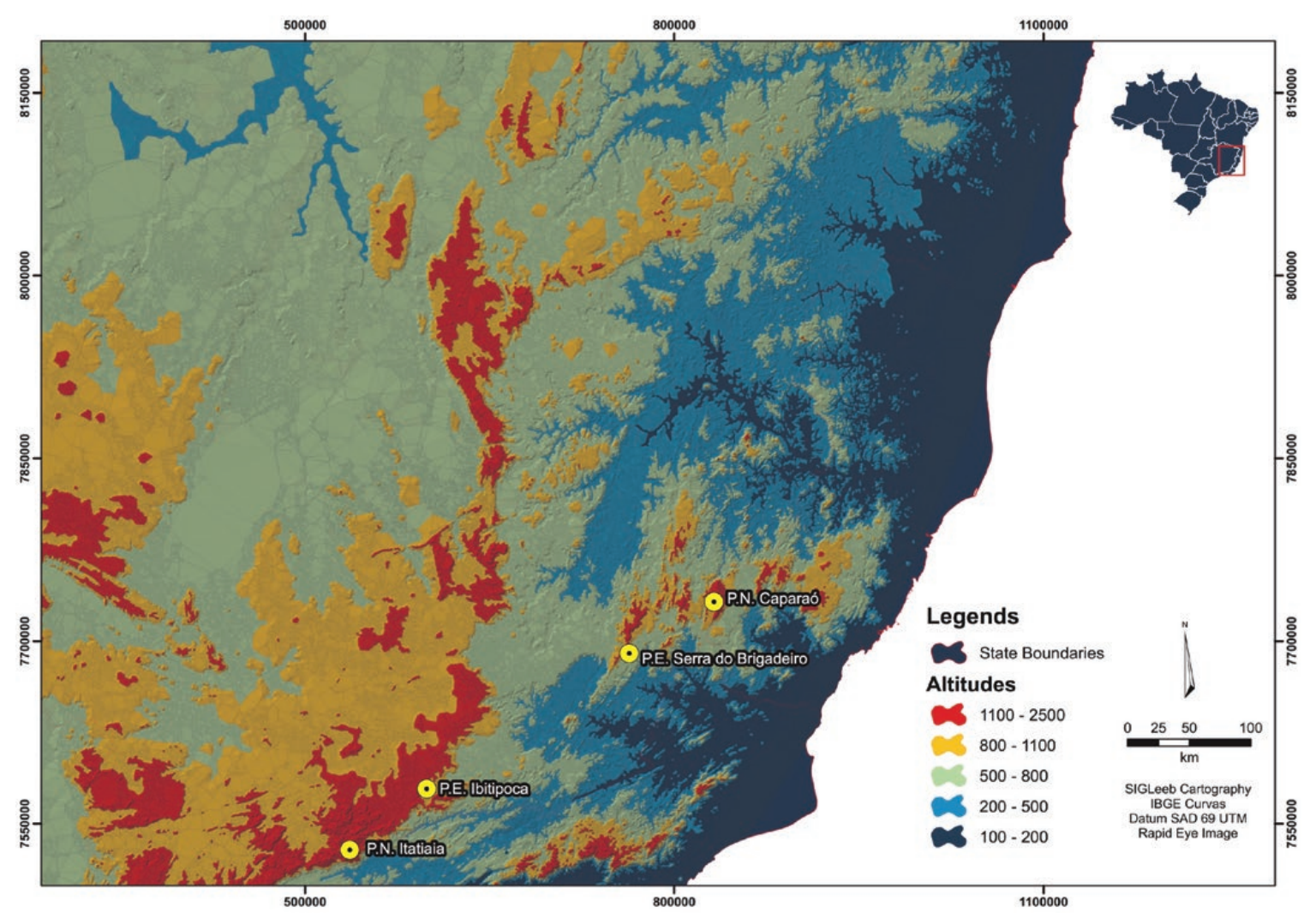

Fig. 1. Map of Mantiqueira Range featuring the four sampled mountains: PEI 'Ibitipoca State Park', PEB 'Brigadeiro State Park', PNC 'Caparaó National Park', and PNI 'Itatiaia National Park'.

types are secondary fragments of semi-deciduous seasonal forest (Veloso et al. 1991) and high-altitude grasslands (Ferri 1980). In a floristic inventory carried out in the high-altitude grasslands of the Brigadeiro State Park, Caiafa and Silva (2005) recorded 81 species of vascular plants with Orchidaceae being the most represented family followed by Asteraceae.

The Caparaó National Park is located between the states of Minas Gerais and Espírito Santo (20 $25^{\prime}$ S, $\left.41^{\circ} 48^{\prime} \mathrm{W}\right)$ (Safford 2001). The soil is predominantly formed by metamorphic rocks (MachadoFilho et al. 1983). The average temperature is $10.5^{\circ} \mathrm{C}$ while the average rainfall is $1,800 \mathrm{~mm}$. The vegetation is composed of secondary fragments of semi-deciduous seasonal forest and high-altitude grasslands above 2,250 $\mathrm{m}$ (Safford 2001).

The Ibitipoca State Park is located in southeastern Minas Gerais $\left(21^{\circ} 42^{\prime} \mathrm{S}\right.$ and $\left.43^{\circ} 54^{\prime} \mathrm{W}\right)$. The soil is predominantly quartzitic (CETEC 1983). The average temperature is $18.9^{\circ} \mathrm{C}$, and the average precipitation is $1,395 \mathrm{~mm}$ (Lemos and Melo-Franco 1976). The climate is classified as wet mesothermal (Köppen classification) (CETEC 1983). It possesses a number of different phytophysiognomies: gramineous fields, rupestrian fields, fields with trees and shrubs, and forest islands (Andrade and Souza 1995). Previous floristic studies have demonstrated the great importance of the Ibitipoca State Park because of its high concentration of biodiversity and large number of endemic species (Rodela 1998, Coelho et al. 2013, Carneiro et al. 2014).

The Itatiaia National Park $\left(22^{\circ} 21^{\prime} \mathrm{S}, 44^{\circ} 40^{\prime} \mathrm{W}\right)$ is located in the central region of the Mantiqueira Range and is markedly seasonal, with cold and dry winters and hot and humid summers. The average temperature is $14^{\circ} \mathrm{C}$ with precipitation of $2,400 \mathrm{~mm}$ (Ribeiro et al. 2007). The climate is classified as mesothermic temperate
(Cwb) (Köppen et al. 2011, Alvares et al. 2013). The high-altitude grasslands are located above $2000 \mathrm{~m}$ and host 550 species (Safford 1999a, b), of which $11 \%$ are endemic.

\section{Sampling of Galling Insects and Host Plants}

The sampling of galling insects was conducted according to the methodology proposed by Fernandes and Price (1988), which has been widely used in studies in several regions of the world (Price et al. 1998, Carneiro et al. 2014). Ten sampling points with herbaceous-shrubby vegetation were chosen at different altitudes of each mountain for a total of 40 such points. The sampling points were spaced at least $1 \mathrm{~km}$ apart. Forest areas were excluded from sampling, as were areas close to trails or areas with visible anthropic interference. A plot was arbitrarily defined at each sampling point by the first 100 woody plants of shrub-size up to $2 \mathrm{~m}$ high encountered, for a total of 1,000 plants per mountain and 4,000 plants for the entire study. Galls were sampled by direct counts in the canopy (see Fernandes and Price 1988, Price et al. 1998, Carneiro et al. 2014). Galling insect species were identified according to the external form of galls and their associated host plants (Price et al. 1998; Blanche 2000; Cuevas-Reyes et al. 2003, 2004a, b; Oyama et al. 2003; Carneiro et al. 2014). Several studies have pointed out that gall form and its associated host plant is a reliable substitute for species in determining the richness of galling insects (see Carneiro et al. 2009).

Galls and host plants were collected and brought to the laboratory for more detailed analyses. All plants and galls were mounted, identified, and deposited in the Herbarium (BHCB) of Department of Botany at Federal University of Minas Gerais. 


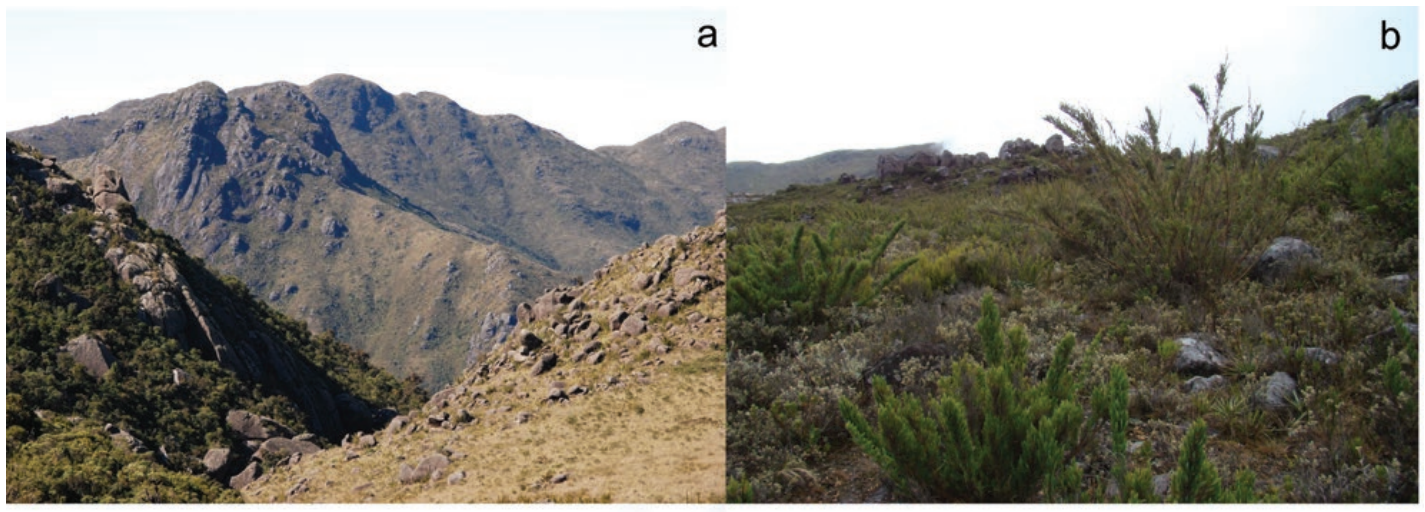

C d

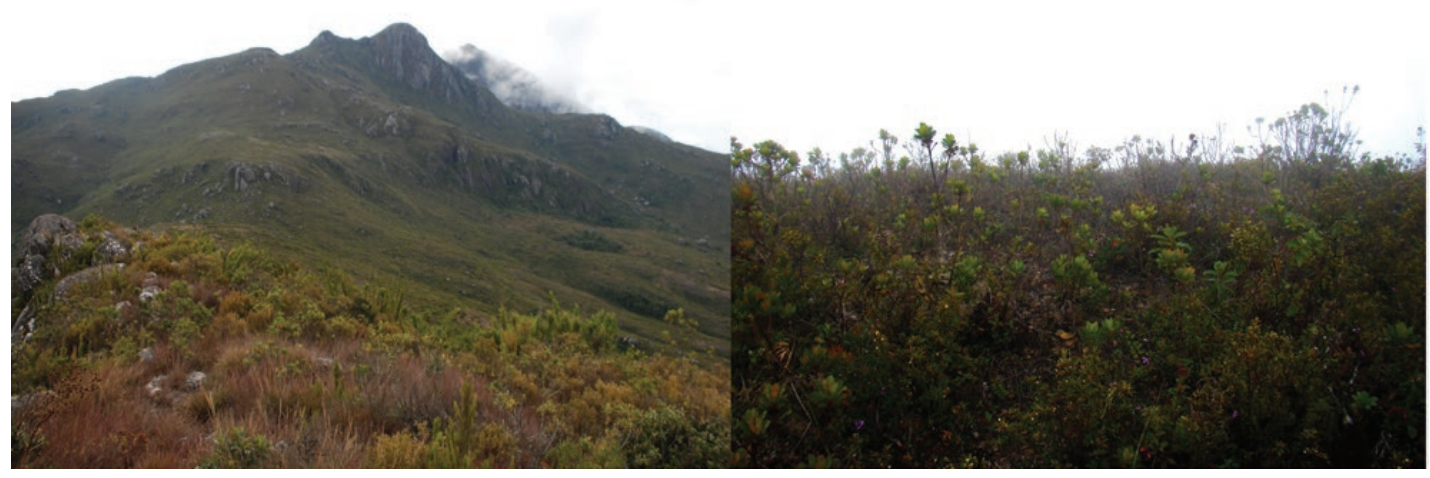

Fig. 2. Local and landscape images of altitudinal fields of mountains associated with Itatiaia National Park (a, landscape view; b, local view) and Caparaó National Park (c, landscape view; d, local view).

Classification of host plant species followed the classification proposed by the 'Angiosperm Phylogeny Group' (APGIV 2016). Detailed descriptions of the galls can be found in Coelho et al. (2013).

\section{Statistical Analysis}

Galling insect richness was analyzed using simple linear regression with a Poisson error distribution. When necessary, regression models with QuasiPoisson and negative binomial error distributions were used in the procedures of 'glm' and 'glm.nb', respectively. The relationship between galling insect richness (variable $y$ ), altitude, and mountain (variable $x$ ) was tested by linear regression with a negative binomial error distribution. When each mountain was analyzed separately, the relationship between galling insect and plant richness was tested using linear regression models with Quasi-Poisson error distribution. To adjust for over-dispersion in the QuasiPoisson model, the F-test was used in place of the Chi-square test (Tjur 1998, Faraway 2006). Finally, all analyses were followed by assessments of residuals to confirm compliance with the assumptions of the models.

At one stage of this work, the additive separation of diversity levels was adopted according to the proposition of Lande (1996): $\gamma=\alpha+\beta$. Gamma diversity was the total number of species of each mountain, while alpha diversity was obtained from the average number of species of the 10 collection sites within each mountain. In this way, beta diversity is obtained by subtracting alpha diversity from gamma diversity, rather than being obtained by division. The approach of additive separation of diversity into its $\alpha$ and $\beta$ components expresses the richness of both in the same unit and allows the direct evaluation of the relative contribution of each to regional diversity, and was adopted only to facilitate the graphical analysis of these components (Loreau 2000, Veech et al. 2002, Crist et al. 2003).
We also attempted to determine the beta diversity-generating processes through a deconstruction approach using the Betapart package (Baselga and Orme 2012). In this step, the multiplicative beta (i.e., range $=\alpha \times \beta$ ) was adopted. According to Baselga (2010), the use of the multiplicative model is mandatory because the independence between alpha and beta is a necessary assumption. Betapart provides a unified theoretical framework for the partitioning of total dissimilarity into its spatial turnover and nesting components. The $\beta$ was deconstructed into two components, the Sørensen $\left(\beta_{\mathrm{SOR}}\right)$ and Simpson $\left(\beta_{\text {SIM }}\right)$ indices. The $\beta_{\text {SIM }}$ represents the spatial turnover of species, and $\beta_{\mathrm{SNE}}$ (obtained by the difference between $\beta_{\mathrm{SOR}}$ and $\beta_{\text {SIM }}$ ) shows the gain or loss of species by nesting (Baselga 2010). To examine the contribution of each sample level to total diversity, an additive partition of the data was made with three diversity scales: $(\alpha 1)$ diversity within plots, $(\beta 1)$ diversity among plots, $(\alpha 2)$ diversity within each mountain, and $(\beta 2)$ diversity among mountains. Multiple-site dissimilarity was computed 1,000 times for randomly sampled subsets of 10 sites (command beta.sample in $\mathrm{R}$ package betapart), and the resulting distributions of $\beta$ SIM and $\beta$ SNE values across the 1,000 samples were used to empirically assess whether there were significant differences. The comparison between the observed and expected diversity for the components ' $\alpha$ ' and ' $\beta$ ' was considered different when $P<0.05$. All analyses were performed with the statistical package R (R Development Core Team 2017).

\section{Results}

In total, 93 species of galling insects were recorded along with 50 species, 30 genera out of a total of 222 plant species sampled. Only $12 \%$ of the galling insects had been recorded in previous studies. The richness of galling insects differed significantly between mountains 
$\left(\chi^{2}=12.261, P<0.006, n=40\right.$; Fig. 3$)$. Significant differences were observed only between Brigadeiro State Park and Ibitipoca State Park, and between Brigadeiro State Park and Itatiaia State Park; Brigadeiro State Park has shown a higher species richness in both cases.

The galling insects richness did not show a negative relationship with altitude $\left(\chi^{2}=2.179, P=0.22\right)$. When the analyses were conducted for each mountain separately, the same pattern was identified. In other words, a negative relationship between galling insect richness and altitude was not found for any of the studied mountains. The number of galling insects increased with the number of plant species $\left(\chi^{2}=5.801, P=0.02\right.$, Fig. 4$)$, but only one mountain showed the pattern of increased galling insects richness with increased plant

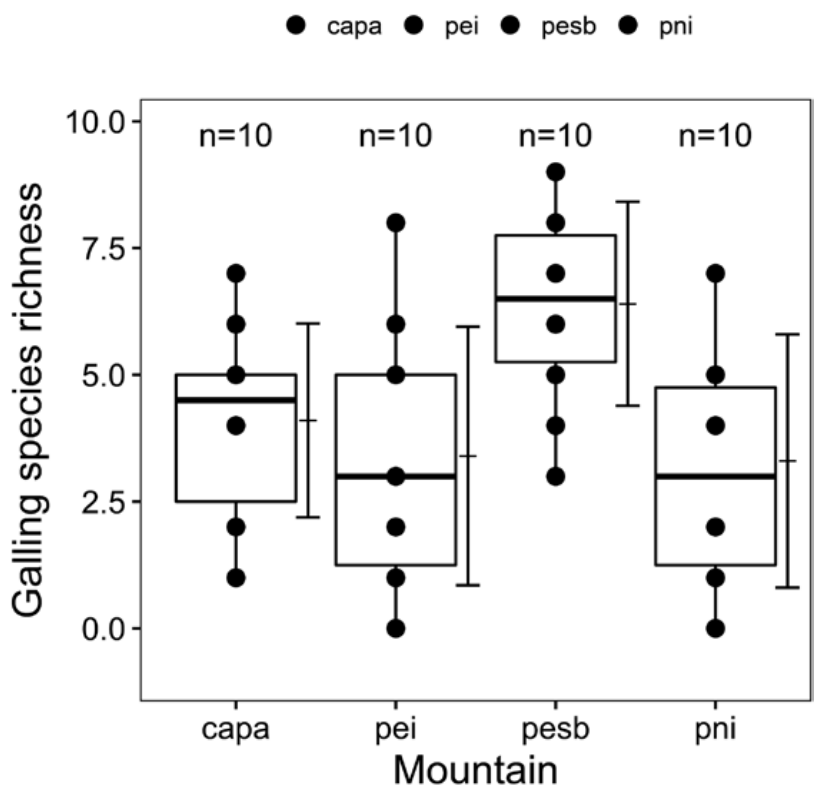

Fig. 3. Mean richness of galling insects in four mountains associated with Mantiqueira Range: PNC 'Caparaó National Park', PEl 'Ibitipoca State Park', PEB 'Brigadeiro State Park', and PNI 'Itatiaia National Park'. Box plot with jittered raw values (strung vertically corresponding to mountains, numbers of sample sites $n$, and mean $\pm \operatorname{SD}$ bars $\left(\chi^{2}=12.261, P<0.006, n=40\right)$.

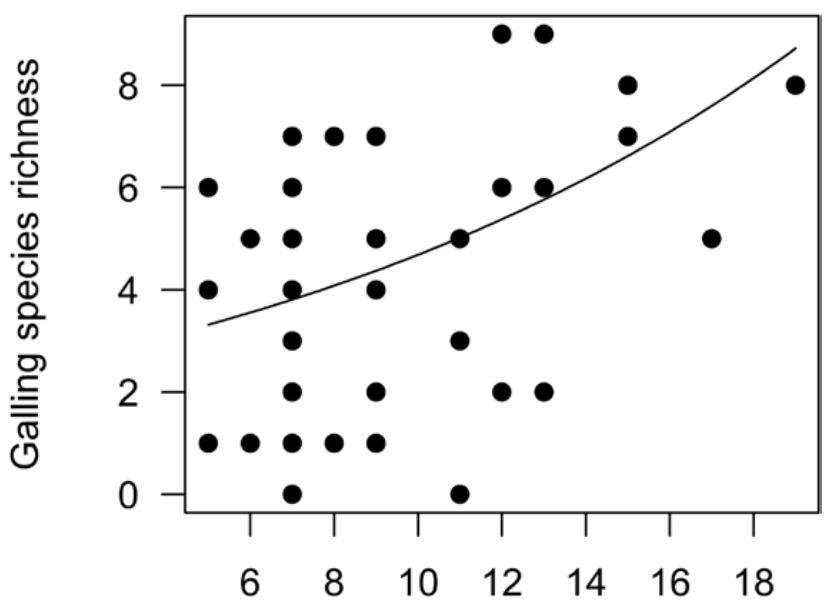

\section{Plant species richness}

Fig. 4. The relationship between richness of galling insects and plant richness for four mountains associated with Mantiqueira Range: PEI 'Ibitipoca State Park', PEB 'Brigadeiro State Park', PNC 'Caparaó National Park', and PNI 'Itatiaia National Park' $\left(\chi^{2}=5.801 ; P=0.02\right.$, equation: galling species richness $=\exp (0.854+0.061 \times$ plant species richness $))$. species richness when mountains were analyzed separately (Ibitipoca State Park: $F_{1.8}=7.561, P=0.03$, Fig. 5)

The additive partition of regional richness $(\gamma)$ into its local and beta components showed that the local diversity $(\alpha)$ of galling insects and plants are relatively low in relation to regional diversity; the beta component $(\beta)$ incorporated most of the regional diversity (Fig. 6). The beta component incorporated $93.22 \%$ for $\beta S O R_{\text {GALLS }}$, and $90.52 \%$ for $\beta S$ OR $_{\text {PLANTS }}$, of the regional diversity of galling insects and host plants, whereas the local component $(\alpha)$ of galling insects and host plants incorporated $6.78 \%$ for $\alpha_{\text {GALLS }}$ and $9.48 \%$ for $\alpha_{\text {PLANTS }}$, respectively, of regional diversity (Figs. 7-9). The multiscale analysis of the additive partition showed similar patterns for galling insects and host plants. The alpha components at the plot scale $\alpha 1_{\text {GALLS }}=5.31 \%, \alpha 1_{\text {PLANTAS }}=9.45 \%$ - were significantly higher than expected. The alpha components at the mountain scale $\alpha 2_{\text {GALLS }}=28 \%, \alpha 2_{\text {PLANTAS }}=46.75 \%$ - were significantly lower than expected. While the beta components at the plot scale $\beta 1_{\text {GALLS }}=22.68 \%, \beta 1_{\text {PLANTAS }}=37.30 \%-$ and at the mountain scale $\beta 2_{\text {GALLS }}=74 \%, \beta 2_{\text {PLANTAS }}=18.81 \%$ - were significantly lower than expected. The beta diversity of galling insects and host plants $\beta S O R_{\text {GALLS }}=93.22 \%, \beta S O R_{\text {PLANTS }}=90.52 \%-$ was driven predominantly by the process of turnover $-\beta$ SIM $_{\text {GALLS }}=88.96 \%$, $\beta S \mathrm{SI}_{\mathrm{PLANTS}}=88.27 \%-$ and minimally by nesting $-\beta S \mathrm{SE}_{\text {GALLS }}$ $=4.25 \%, \beta \mathrm{SNE}_{\mathrm{PLANTS}}=2.25 \%$, in relation to regional diversity (Figs. 7-9).

\section{Discussion}

Species richness of galling insects has been reported to decrease with increasing altitude in various biogeographical regions of the world. Using secondary data from the Old World (Indonesia), Fernandes and Lara (1993) demonstrated this relationship for galling insects along an altitudinal gradient of $3,400 \mathrm{~m}$. With data from Arizona and southeastern Brazil extracted from paired samplings conducted in mesic and xeric environments, altitude was identified as the variable that best explained galling insects richness in xeric environments (Fernandes and Price 1988, Lara et al. 2002). The authors argued that high species richness of galling insects is more

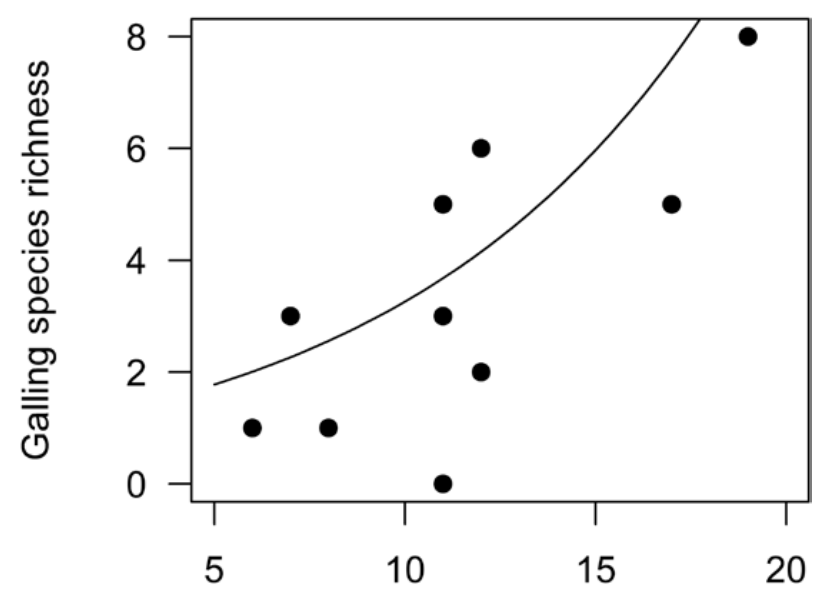

Plant species richness

Fig. 5. Relationship between richness of galling insects and plant richness in PEl 'Ibitipoca State Park' $\left(F_{1.8}=7.561, P=0.03\right.$, equation: galling insect richness $=\exp (-0.028+0.121 \times$ plant species richness $))$. 

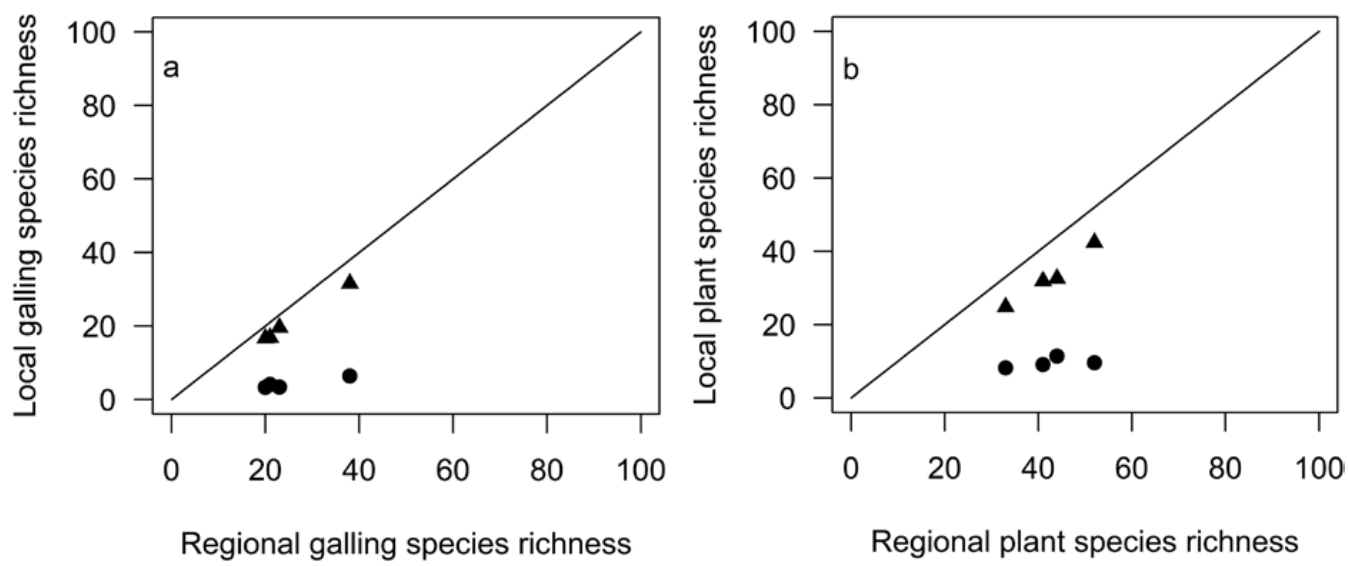

Fig. 6. Relationship between regional richness and local richness of plants (a) and galling insects (b) in four mountains associated with Mantiqueira Range: PEI 'Ibitipoca State Park', PEB 'Brigadeiro State Park', PNC ‘Caparaó National Park', and PNI 'Itatiaia National Park'. Local richness or $\alpha$ (filled circles) of galling insects is low compared with regional richness; beta richness $\beta$ (filled triangles) makes up most of the regional richness. The diagonal line is the theoretical limit (local richness = regional richness).
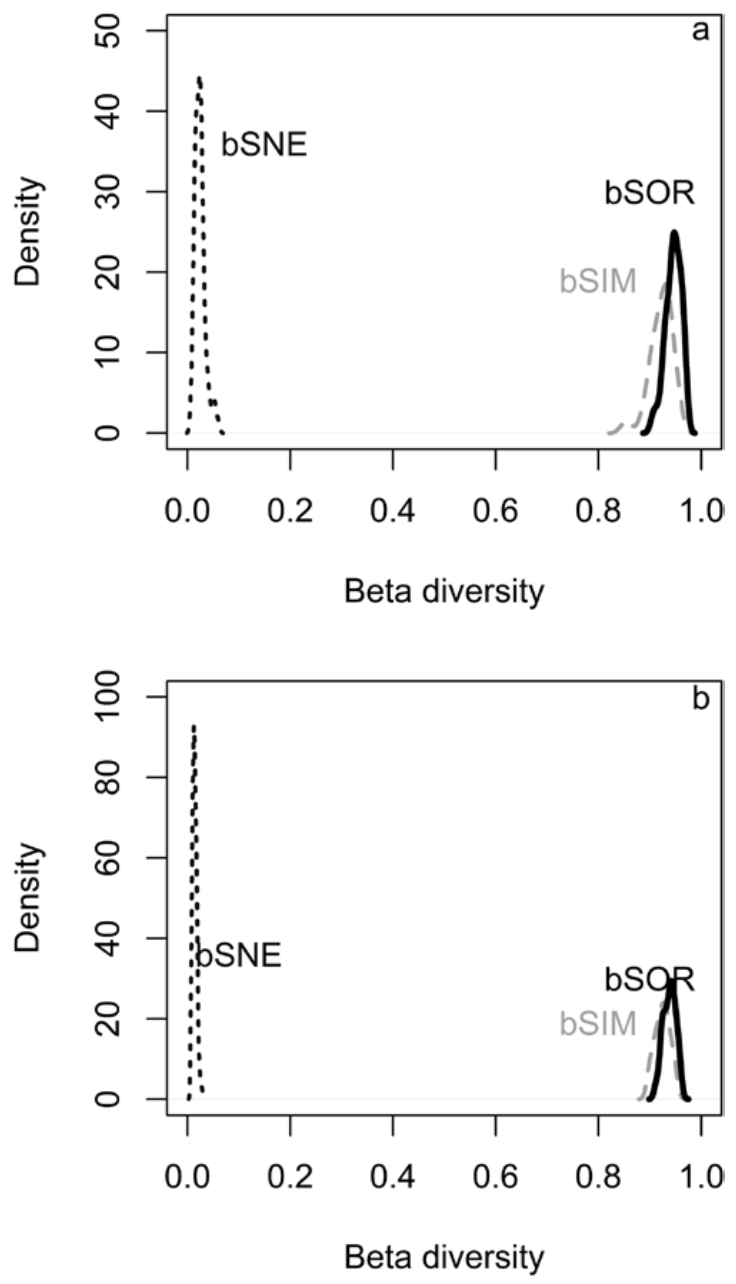

Fig. 7. Density plots representing the distribution of the $\beta_{\mathrm{SOR}}$ (solid line) into $\beta_{\text {SIM }}$ (dashed gray line) and $\beta_{\text {SNE }}$ (dashed black line) across 1,000 samples of 10 sites from each data set: (a) galling insects; (b) plants.

associated with sclerophyllic vegetation, which is characteristic of plants in xeric environments, than altitude per se. Sclerophyllic vegetation, which is common in extreme environments, has long-lived leaves and elevated dry weight, and is rich in defense compounds, protecting the guild of galling insects against predators (Fernandes and Price 1988). In this study, altitude did not affect species richness of galling insects. Despite the relatively short altitudinal range $(1,281 \mathrm{~m})$, an important factor that can obscure patterns of species richness of galling insects relative to altitude is the presence of super-hosts. High-altitude grasslands 'campos de altitude' are mosaics of different vegetation types with a predominance of shrub species, especially those belonging to the genus Baccharis (Asterales: Asteraceae) (Safford 1999a,b, 2001, 2007). According to Fernandes et al. (1996, 2014a,b), Baccharis may be the most species-rich genus in the Neotropical Region. This statement was supported by the present study, which found Baccharis to possess $40 \%$ of galling insect species, while Tibouchina (Myrtales: Melastomataceae) possessed only $12 \%$ (see Coelho et al. 2013). The occurrence of super-hosts along the altitudinal gradient, and especially the mountain tops, can increase species richness, thereby obscuring the effect of hygrothermal stress (Carneiro et al. 2014).

Galling insect richness was found to increase with plant richness. Considering that galling insects are specialists, an increase in plant richness is directly related to an increase in niches available for female oviposition and, consequently, an increase in the richness of insect specialists (Southwood 1960, 1961; Strong et al. 1984). A study employing extensive standardized sampling in the Serra do Espinhaço found host plant richness to be the factor that best explained the increase of galling insects independently of the altitude effect (Carneiro et al. 2014).

The results reported so far in the literature on the effects of host plant richness are controversial. Many studies corroborated the positive effects of host plants on galling insect richness (e.g., Wright and Samways 1996, 1998; Gonçalves-Alvim and Fernandes 2001; Oyama et al. 2003; Cuevas-Reyes et al. 2004b), while others did not observe significant effects in this relationship (e.g., Fernandes and Price 1988, Blanche 2000, Lara et al. 2002, Araújo 2013). These seemingly contradictory results point to important local effects, which can be identified by analyzing the different components of diversity (see below). The local occurrence of super-hosts may also explain the absence of patterns between galling insect richness and host plants. As in the case of altitude, habitats with low host plant richness, but with the presence of super-hosts, can concentrate high richness of galling insects. On the other hand, habitats very rich in 

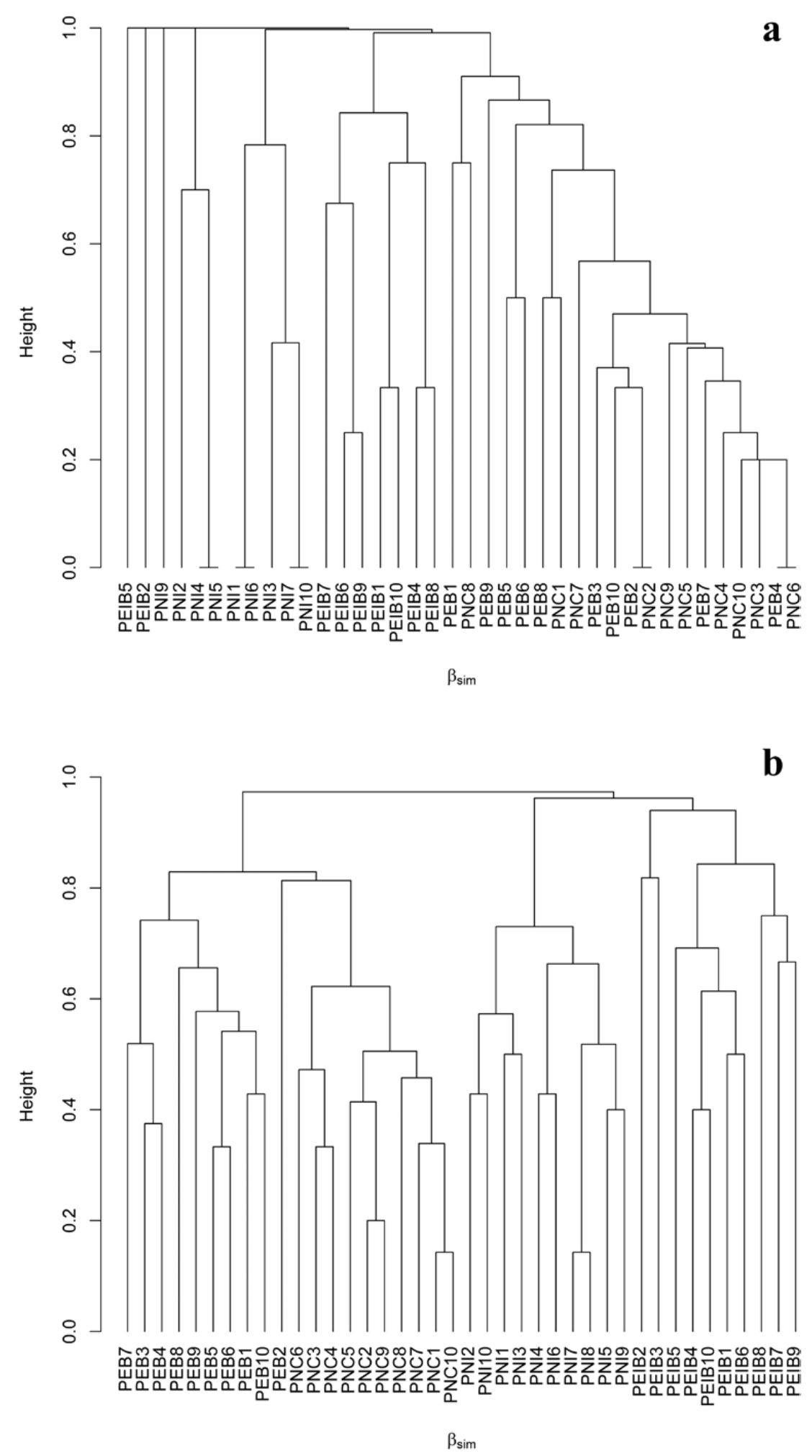

Fig. 8. Clustering using the average linkage of the $\beta_{\text {simpson }}$ components for insect galls (cluster ' $a$ ') and for host plants (cluster ' $b$ ') between sample plots located on four mountains -10 samples from each mountain.

host plants, but without super-hosts, can show a low richness of galling insects (Carneiro et al. 2014). In this study, we believe that the presence of the genus Baccharis (Asteraceae) may have weakened the patterns, especially in two of the mountains (Caparaó National
Park and Itatiaia National Park) where the genus was very abundant and represented more than $50 \%$ of the total individuals sampled.

Despite the lack of standardization of samples in previous works, the evidence accumulated so far suggests that the distribution of galling insects exhibits low similarity among sampling sites (see Blanche 

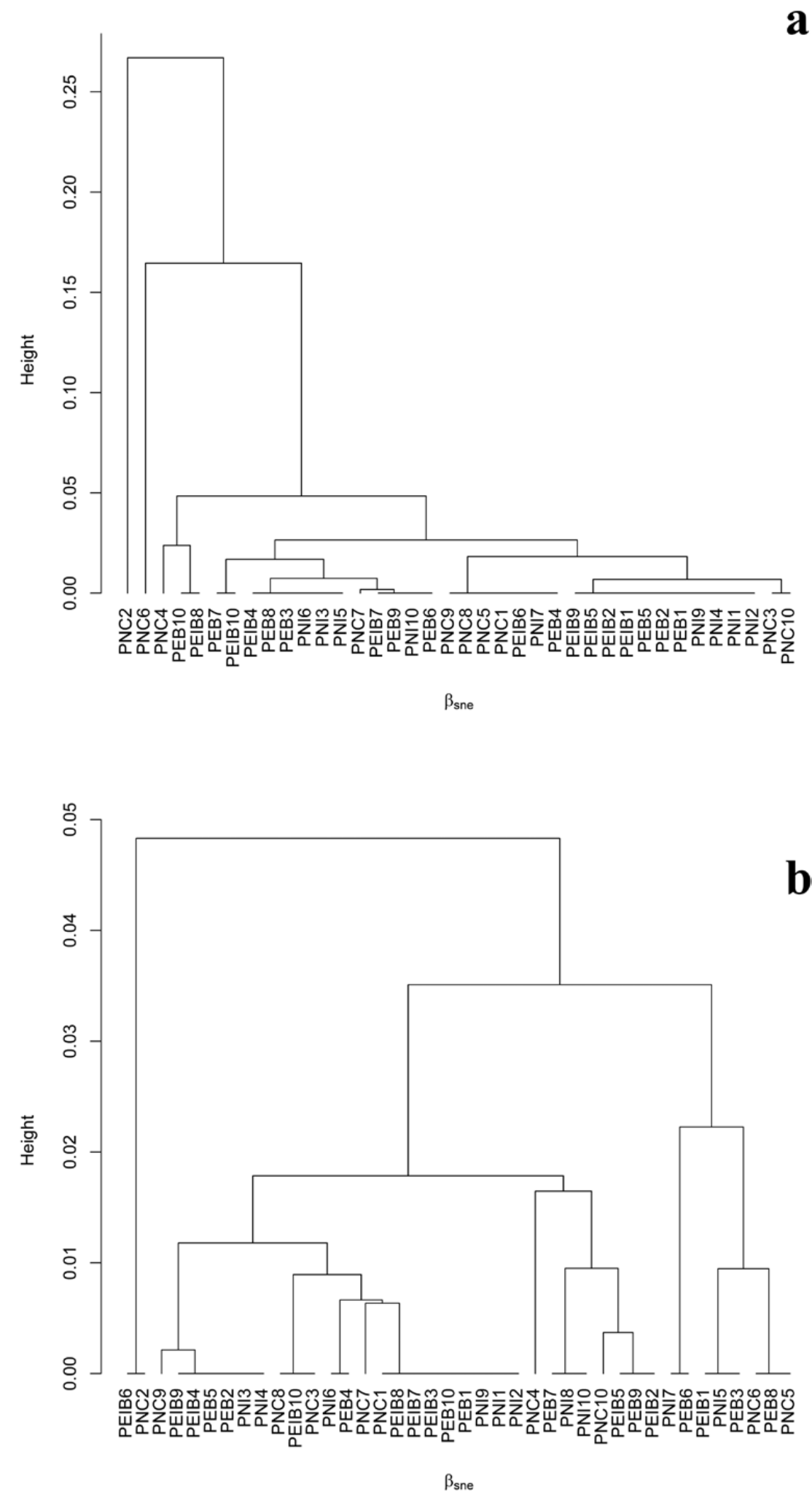

Fig. 9. Clustering using the average linkage of the $\beta_{\mathrm{SNE}}$ components for insect galls (cluster ' $a$ ') and for host plants (cluster ' $b$ ') between sample plots located on four mountains -10 samples from each mountain.

and Westoby 1996, Gonçalves-Alvim and Fernandes 2001, CuevasReyes et al. 2003, Medianero et al. 2010, Carneiro et al. 2014). The results of this work corroborate such evidence. The additive partition of regional richness $(\gamma)$ in its local and beta component showed that local richness $(\alpha)$ of galling insect species and host plants is lower than regional richness; and that the beta component $(\beta)$ incorporates most of the regional richness. It is also possible to conclude a correlation between local and regional richness (see Fig. 6). Many critics have emerged around the interpretation of the correlation between local and regional diversity face an already demonstrated scale dependence (Fig. 6). For Loreau (2000), local diversity could be seriously constrained by the scale. The physical constrains 
of small scales could drive local and regional curves to a saturated pattern of communities, but in this case, not in consequence of biotic interactions (e.g., competition). The sample design of the local scale can be classified as small in our study. Despite the possible physical constrains highlighted by Loreau (2000), we have found evidences of an unsaturated communities for both, galling insects and plants, pointing to no interactive forces driving the patterns. The conclusions about the correlation between the local and regional richness should not be analyzed independently of beta diversity and it process under a multiple-scale approach - turnover and nestedness - as we intended in the followed discussion (Price 1997). In addition, the multiscale analysis of the additive partitioning of the diversity showed similar patterns for galling insects and host plants for plot and mountain scales, and the beta component contributed the most to the regional diversity on both scales. These results, although in agreement with indications present in the literature, should be analyzed in an idiosyncratic way, since the drivers generating this pattern are unique for each studied physiognomy.

The beta diversity for galling insects and host plants was mainly due to the turnover process and minority due nesting. The results have shown that in high-altitude grasslands there are abrupt changes in floristic composition between habitats along the altitudinal gradient. These abrupt changes may reflect geographical isolation due to barriers imposed by relief, topography, and soil patches (Carneiro et al. 2014, Coelho et al. 2017). Highaltitude grasslands are formed by shrub vegetation and small and slow-growing trees immersed in a grassy matrix. This vegetation is closely controlled by topography, drainage systems, and the distribution of soil types. Therefore, the high diversity of vegetation is attributed to the mosaic of environments formed by several soil classes, rugged relief, and microclimatic variation (Safford 2001). These characteristics favor disjoint populations, often restricted to mountains geographically isolated (Safford 2001). As a result, there is a large number of species, high endemism of plants, and consequently a great discontinuity in the composition of plant species and their associated herbivores. In addition, high-altitude grasslands are immersed in the phytogeographical domain of the Atlantic Forest; therefore, abrupt ecotones comprised by tree lines isolate them from the wet forests located at lower altitudes (Safford 2007). Fire has also been identified as an important evolutionary factor for the speciation process and radiation of galling insects in gramineous fields due to frequent and synchronous regrowth of vegetation (Mendonça 2001, Price 2003). This can be, along with plant composition and richness, one of the most important processes driving the differences between regional galling insects richness (Safford 2001, Coelho et al. 2017).

Although the composition of galling insect and plant species differs among sample sites and mountains, local richness remains relatively low. Our results indicate that the spatial distribution of galling insects is better explained by historical factors, such as the distribution of genera and host species, as well as their relation to habitat than primary effects, such as hygrothermal stress - here represented by altitude. In addition, the data also demonstrated that the mountains of Mantiqueira Range contribute fundamentally to the regional diversity of galling insects and plants. Therefore, designs should incorporate multiple spatial scales into future conservation strategies. Thus, the addition of local habitats with different landscapes substantially affects the regional galling and plant richness for the mountain scale, and their conservation can be delineated by the incorporation of small landscapes with different characteristics instead of a single large and homogenous landscape.

\section{Acknowledgments}

This study was conducted in partial fulfillment of the M.Sc. requirements for M.S.C. We are also grateful for grants and logistic support provided by the Conselho Nacional de Pesquisa (CNPq), Fundação de Amparo à Pesquisa de Minas Gerais (FAPEMIG), and Fundação de Amparo a Pesquisa de São Paulo (FAPESP).

\section{References Cited}

Abrahamson, W. G., and A. E. Weis. 1997. Evolutionary ecology across three trophic levels: goldenrods, gallmakers and natural enemies. Princeton University Press, New Jersey.

Alvares, C. A., J. L. Stape, P. C. Sentelhas, J. L. De. Moraes, and G. Sparovek. 2013. Köppen's climate classification map for Brazil. Meteorol. Zeitschrift. 22: 711-728.

Andrade, P. M., and H. C. Souza. 1995. Contribuição ao conhecimento da vegetação do Parque Estadual do Ibitipoca, Lima Duarte Minas Gerais. Rev. Árvore. 19: 249-261.

APG IV. 2016. An update of the angiosperm phylogeny group classification for the orders and families of flowering plants: APG IV. Bot. J. Linn. Soc. 181: 1-120.

Araújo, W. S. 2013. Different relationships between galling and non-galling herbivore richness and plant species and plant species richness: a meta-analysis. Arthropod Plant Interact. 7: 373-377.

Araújo, W. S., C. Scareli-Santos, F. A. G. Guilherme, and P. Cuevas-Reyes. 2013. Comparing galling insect richness among Neotropical savannas: effects of plant richness, vegetation structure and super-host presence. Biodivers. Conserv. 22: 1083-1094.

Barreto, H. L. 1949. Regiões fitogeográficas de Minas Gerais. B. Geo. 14: 14-28.

Baselga, A. 2010. Partitioning the turnover and nestedness componentes of beta diversity. Global Ecol. Biogeogr. 19: 134-143.

Baselga, A., and C. D. L. Orme. 2012. Betapart: an R package for the study of beta diversity. Method Ecol. Evol. 3: 808-812.

Beckage, B., B. Osborne, G. Gavin, C. Pucko, T. Siccama, and T. Perkins. 2008. A rapid upward shift of a forest ecotone during 40 years of warming in the Verde Mountains of Vermont. PNAS 105: 4197-4202.

Blanche, K. R. 2000. Diversity of insect induced galls along a temperature-rainfall gradient in the tropical savannah region of the Northern territory, Australia. Austral. Ecol. 25: 311-318.

Blanche, K. R., and J. A. Ludwig. 2001. Species richness of gall-inducing insects and host plants along an Altitudinal gradient in big bend national park, Texas. Am. Midl. Nat. 154: 219-232.

Blanche, K. R., and M. Westoby. 1996. The effect of the taxon and geographic range size of host eucalypt species on the species richness of gall-forming insects. Australian J. Ecol. 21: 332-335.

Caiafa, N. A., and A. F. Silva. 2005. Composição florística e espectro biológico de um campo de altitude no Parque Estadual da Serra do Brigadeiro, Minas Gerais- Brasil. Rodriguésia 56: 163-173.

Carneiro, M. A. A., G. W. Fernandes, and O. F. F. DeSouza. 2005. Convergence in the variation of local and regional galling species richness. Neotrop. Entomol. 34: 547-553.

Carneiro, M. A. A., R. A. X. Borges, A. P. A. Araújo, and G. W. Fernandes. 2009. Insetos indutores de galhas da porção sul da Cadeia do Espinhaço, Minas Gerais, Brasil. Rev. Bras. Entomol. 53: 570-592.

Carneiro, M. A. A., M. S. Coelho, and G. W. Fernandes. 2014. Chapter 7: Galls in Brazilian Mountains: new reports and perspectives, pp. 129-156. In G. W. Fernandes and J. C. Santos (eds.), Neotropical insect galls. Springer, The Netherlands and London.

CETEC. 1983. Diagnóstico ambiental do estado de Minas Gerais. Fundação Centro Tecnológico de Minas Gerais/CETEX, Belo Horizonte, Brazil.

Coelho, M. S., M. A. A. Carneiro, C. S. A. Branco, R. A. X. Borges, and G. W. Fernandes. 2013. Gall-inducing insects from Campos de Altitude, Brazil. Biota. Neot. 13: 139-151.

Coelho, M. S., M. A. A. Carneiro, C. A. Branco, R. A. X. Borges, and G. W. Fernandes. 2017. Species turnover drives $\beta$-diversity patterns across multiple spatial scales of plant-galling interactions in mountaintop grasslands. PLoS ONE. (in press). 
Crist, T. O., J. A. Veech, J. C. Gering, and K. S. Summerville. 2003. Partitioning species diversity across landscapes and regions: a hierarchical analysis of a, b, and c-diversity. Am. Nat. 162: 734-743.

Cuevas-Reyes, P., C. Siebe, M. Martinez-Ramos, and K. Oyama. 2003. Species richness of gall-forming insects in a tropical rain forest: correlations with plant diversity and soil fertility. Biodivers. Conserv. 12: 411-422.

Cuevas-Reyes, P., M. Quesada, P. Hanson, R. Dirzo, and K. Oyama. 2004a. Diversity of gall-inducing insects in a Mexican tropical dry Forest: the importance of plant species richness, life forms, host plant age and plant density. J. Ecol. 92: 707-716.

Cuevas-Reyes, P., M. Quesada, C. Siebe, and K. Oyama. 2004b. Spatial patterns of herbivory by gallforming insects: a test of the soil fertility hypothesis in a Mexican tropical dry forest. Oikos 107: 181-189.

Dreger-Jauffret, F., and J. D. Shorthouse. 1992. Diversity of gall-inducing insects and their galls, pp. 8-34. In J. D. Shorthouse and O. Rohfritsch (eds.), Biology of insect-induced galls. Oxford University Press, Oxford.

Engevix. 1995. Caracterização do meio físico da área autorizada para criação do Parque Estadual da Serra do Brigadeiro - Relatório técnico final dos estudos. Instituto Estadual de Floresta, Belo Horizonte, Brazil.

Espírito-Santo, M. M., and G. W. Fernandes. 2007. How many species of gall-inducing insects are there on earth, and where are there? Ann. Entomol. Soc. Am. 100: 95-99.

Faraway, J. J. 2006. Extending linear models with R: generalized linear, mixed effects and nonparametric regression models. Boca Raton, FL and London.

Fernandes, G. W., and A. C. F. Lara. 1993. Diversity of Indonesian gall-forming herbivores along altitudinal gradients. Biodivers. Lett. 1: 186-192.

Fernandes, G. W., and P. W. Price. 1988. Biogeographical gradients in galling species richness: tests of hypotheses. Oecologia 76: 161-167.

Fernandes, G. W., and P. W. Price. 1991. Comparison of tropical and temperate galling species richness: the roles of environmental harshness and plant nutrient status, pp. 91-115. In P. W. Price, T. M. Lewinsohn, G. W. Fernandes, and W. W. Benson (eds.), Plant-animal interactions: evolutionary ecology in tropical and temperate regions. John Wiley, New York, NY.

Fernandes, G. W., and P. W. Price. 1992. The adaptive significance of insect gall distribution: survivorship of species in xeric and mesic habitats. Oecologia 90: 14-20.

Fernandes, G. W., A. C. F. Lara, and P. W. Price. 1994. The geography of galling insects and the mechanisms resulting in patterns, pp. 42-48. In P. W. Price, W. J. Mattson, and Y. Baranchikov (eds.), Gall-forming insects: ecology, physiology and evolution. Forest Service - US Department of Agriculture, St. Paul, MN.

Fernandes, G. W., M. A. A. Carneiro, A. C. F. Lara, L. R. Allain, G. I. Andrade, G. R. Julião, T. R. Reis, and I. M. Silva. 1996. Galling insects on neotropical species of Baccharis (Asteraceae). Trop. Zool. 9: 315-332.

Fernandes, G. W., S. J. Gonçalves-Alvim, and M. A. A. Carneiro. 2005 Habitat-driven effects on the diversity of gall-inducing insects in the Brazilian cerrado, pp. 693-708. In A. Raman, C. W. Schaefer, and T. W. Withers (eds.), Biology, ecology and evolution of gall-inducing arthropods. Science Publishers, Washington, DC.

Fernandes G. W., M. S. Coelho, and J. C. Santos. 2014a. Neotropical insect galls: status of knowledge and perspectives, pp. 1-14. In G. W. Fernandes and J. C. Santos (eds.), Neotropical insect galls. Springer, Washington, DC.

Fernandes, G. W., J. O. Silva, M. M. Espírito-Santo, M. Fagundes, Y. Oki, and M. A. A. Carneiro. 2014b. Baccharis: a Neotropical Model System to study insect plant interactions, pp. 193-219. In G. W. Fernandes and J. C. Santos (eds.), Neotropical insect gGalls. Springer, Washington, DC.

Ferri, M. G. 1980. Vegetação Brasileira. Editora da Universidade de São Paulo, São Paulo, Brazil.

Gonçalves-Alvim, S. J., and G. W. Fernandes. 2001. Biodiversity of galling insects: historical, community and habitat effects in four Neotropical savannas. Biodivers. Conserv. 10: 79-98.

Hawkins, B. A., and S. G. Compton. 1992. African fig wasp communities: undersaturation and latitudinal gradients in species richness. J. Anim. Ecol. 61: 361-372.

Julião, G. R., E. M. Venticinque, G. W. Fernandes, and P. W. Price. 2014 Unexpected high diversity of galling insects in the Amazonian upper canopy: the savanna out there. PLoS ONE 9: e114986.
Köppen, W., E. Volken, and S. Brönnimann. 2011. The thermal zones of the Earth according to the duration of hot, moderate and cold periods and to the impact of heat on the organic world. Meteorol. Zeitschrift. 20: 351-360.

Lande, R. 1996. Statistics and partioning of species diversity and similarity among multiple communities. Oikos 76: 5-13.

Lara, A. C. F., and G. W. Fernandes. 1996. The highest diversity of galling insects: Serra do Cipó, Brazil. Biodivers. Lett. 3: 111-114.

Lara, A. C. F., G. W. Fernandes, and S. J. Gonçalves-Alvim. 2002. Tests of hypotheses on patterns of gall distribution along an altitudinal gradient. Trop. Zool. 15: 219-232.

Lemos, A. B., and M. V. Melo-Franco. 1976. Situação atual dos Parques Florestais e Reservas Biológicas de Minas Ferais. F. J. P. 6: 33-41.

Lomolino, M. V. 2001. Elevation gradientes of species-density: historical and prospective views. Global Ecol. Biogeogr. 10: 3-13.

Loreau, M. 2000. Are communities saturated? On the relationship $\alpha, \beta$, and $\gamma$ diversity. Ecol. Lett. 3: 73-76.

Machado-Filho, L., M. W. Ribeiro, S. R. Gonzalez, C. A. Schenini, A. SantosNeto, R. C. B. Palmeira, J. L. Pires, W. Teixeira, and H. E. F. Castro. 1983 Geologia, pp. 56-66. In Projeto RADAMBRASIL (eds.), O projeto, Rio de Janeiro, Brazil.

Martinelli, G. 2007. Mountain biodiversity in Brazil. Rev. Bras. Bot. 30: 587-597.

Medianero, E., A. Ibáñez, and J. L. Nieves-Aldrey. 2010. The importance of beta diversity in local gall-inducing arthropod distribution. Neotrop. Entomol. 39: 365-370.

Mendonça, M. D. S. 2001. Galling insect diversity patterns : the resource synchronisation hypothesis. Oikos 95: 171-176.

Moreira, A. A. N., and Camelier, C. 1977. Relevo. Geografia do Brasil: Região Sudeste, Rio de Janeiro. Fundação Instituto Brasileiro de Geografia e Estatística, Rio de Janeiro, Brazil.

Nyman, T., and R. Julkunen-Tiitto. 2000. Manipulation of the phenolic chemistry of willows by gall-inducing sawflies. PNAS 97: 13184-13187.

Oyama, K., M. A. Pérez-Pérez, P. Cuevas-Reyes, and R. Luna-Reyes. 2003. Regional and local species richness of gall-inducing insects in two tropical rain forests in Mexico. J. Trop. Ecol. 19: 595-598.

Price, P. W. 1997. Insect ecology. Wiley, New York, NY.

Price, P. W. 2003. Macroevolutionary theory on macroecological patterns. Cambridge University Press, Cambridge.

Price, P. W., G. L. Waring, and G. W. Fernandes. 1986. Hypotheses on the adaptive nature of galls. Proc. Entomol. Soc. Wash. 88: 361-363.

Price, P. W., G. W. Fernandes, A. C. F. Lara, J. Brawn, D. Gerling, H. Barrios, M. G. Wright, S. P. Ribeiro, and N. Rothcliff. 1998. Global patterns in local number of insect galling species. J. Biogeogr. 25: 581-591.

Raman, A. 2007. Insect-induced plant galls of India: unresolved questions. Curr. Sci. 92: 748-757.

R Development Core Team. 2017. R: a language and environment for statistical computing. Version 3.3.3. R Foundation for Statistical Computing, Vienna, Austria. http://www.rproject.org.

Ribeiro, S. P., and Y. Basset. 2007. Gall-forming and free-feeding herbivory along vertical gradients in a lowland tropical rainforest: the importance of leaf sclerophylly. Ecography 30: 663-672.

Ribeiro, K. T., B. M. O. Medina, and F. R. Scarano. 2007. Composição de espécies e relações biogeográficas da flora sobre afloramentos rochosos no Planalto do Itatiaia, SE do Brasil. Rev. Bras. Bot. 30: 623-639.

Rizzini, C.T. 1963. Nota prévia sobre a divisão fitogeográfica do Brasil. Separata da Revista Brasileira de Geografia. Instituto Brasileiro de Geografia Estatística, Rio de Janeiro, Brazil.

Rizzini, C. T. 1979. Tratado de fitogeografia do Brasil. Hucitec, São Paulo, Brazil.

Rodela, L. C. 1998. Cerrados de altitude e campos rupestres do Parque Estadual de Ibitipoca, sudeste de Minas Gerais: distribuição e florística por subfisionomias da vegetação. Rev. Dep. Geog. USP 12: 163-189.

Safford, H. D. 1999a. Brazilian Páramos. I. An introduction to the physical environment and vegetation of the campos de altitude. J. Biogeogr. 26 : 693-712.

Safford, H. D. 1999b. Brazilian Páramos. II. Macro- and mesoclimate of the campos de altitude and affinities with high mountain climates of the tropical Andes and Costa Rica. J. Biogeogr. 26: 713-737. 
Safford, H. D. F. 2001. Brazilian paramos. III. Patterns and rates of postfire regeneration in the campos de altitude. Biotropica 33: 282-302.

Safford, H. D. 2007. Brazilian Páramos. IV. Phytogeography of the campos de altitude. J. Biogeog. 34: 1701-1722.

Shorthouse, J. D., D. Wool, and A. Raman. 2005. Gall-inducing insect Nature's most sophisticated herbivores. Basic Appl. Ecol. 6: 407-411.

Southwood, T. R. E. 1960. The abundance of the Hawaiian trees and the number of their associated insect species. PNAS 17: 299-303.

Southwood, T. R. E. 1961. The number of species associated with various trees. J. Anim. Ecol. 30: 1-8.

Stone, G. N., and K. Schönrogge. 2003. The adaptive significance of insect gall morphology. Trends Ecol. Evol. 18: 512-522.

Strong, D. R., J. H. Lawton, and T. R. E. Southwood. 1984. Insects on plants. Blackwell, Oxford, UK.

Tjur, T. 1998. Nonlinear regression, quase likelihood, and overdispersion in generalized models. Am. Stat. 52: 222-227.

Veech, J. A., K. S. Summerville, T. O. Crist, and J. C. Gering. 2002. The additive partitioning of diversity: recent revival of an old idea. Oikos 99: 3-9.
Veldtman, R., and M. A. McGeoch. 2003. Gall-forming insect species richness along a nonscleromorphic vegetation rainfall gradient in South Africa: the importance of plant community composition. Austral. Ecol. 28: 1-13.

Veloso, H. P., A. L. R. Rangel Filho, and J. C. A. Lima. 1991. Classificação da vegetação brasileira, adaptada a um sistema universal. Departamento de Recursos Naturais e Estudos Ambientais, Rio de Janeiro, Brazil.

Waring, G. L., and P. W. Price. 1990. Plant water stress and gall formation (Cecidomyiidae: Asphondylia spp.) on creosote bush. Ecol. Entomol. 15: 87-95.

Weis, A. E., R. Walton, and C. L. Crego. 1988. Reactive plant tissue sites and the population biology of gall makers. Annu. Rev. Entomol. 33: 467-486.

Whittaker, R. H. 1972. Evolution and measurement of species diversity. Taxon 21: 213-251.

Wright, M. G., and M. J. Sanways. 1996. Gall-insect species richness in African Fynbos and Karoo vegetation: the importance of plant species richness. Biodivers. Lett. 3: 151-155.

Wright, M. G., and M. J. Samways. 1998. Insect species richness tracking plant species richness in a diverse flora: gall-insects in the Cape Floristic Region, South Africa. Oecologia 115: 427-433. 